\title{
Distinct Clonotypes of Anti-DNA Antibodies in Mice with Lupus Nephritis
}

\author{
Haruyoshi Yoshida, Michiko Yoshida, Shozo Izui, and Paul Henri Lambert \\ World Health Organization Immunology Research and Training Centre, Department of Pathology, Centre Medical Universitaire \\ and Centre de Transfusion, Hôpital Cantonal Universitaire, 1211 Geneva 4, Switzerland
}

\begin{abstract}
Clonotypes of IgG anti-DNA antibodies were studied by isoelectric focusing in various autoimmune mice with or without lethal lupus nephritis. MRL/MpJ-lpr/lpr mice exhibited the most heterogeneous spectrotypes of anti-DNA antibodies in the $\mathrm{pH}$ range from 6.5 to 8.5 , with marked variation in individual mice. Female $(\mathrm{NZB} \times \mathrm{NZW}) \mathrm{F1}$ mice expressed rather uniform DNA-binding bands composed of at least five to six distinct subgroups, having isoelectric points from 6.5 to 8.0. Male BXSB mice showed major characteristic bands confined to alkaline $\mathrm{pH}$ range from 7.8 to 8.5 , similar to C57BL/6J-lpr/lpr mice, which showed markedly restricted bands in this region. Both AKR/J-lpr/lpr and C3H/HeJ-lpr/ lpr mice expressed DNA-binding bands mostly focused between pH 6.5 and 8.2. The aging study indicated that three autoimmune mice (MRL/MpJ-lpr/lpr, [NZB $\times$ NZW]F1, and male BXSB) that developed fatal glomerulonephritis showed clonal expansion of anti-DNA antibodies throughout their life. In contrast, such age-dependent expansion of anti-DNA clonotypes was not evident in three lpr cogenic mice (C57BL/6J-lpr/lpr, $A K R / J-l p r / l p r$, and $\mathrm{C3H} / \mathrm{HeJ}-l p r / l p r)$ that developed only mild glomerulonephritis; rather, their expression of anti-DNA spectrotypes diminished as they aged. Anti-DNA activities in renal eluates from nephritic autoimmune mice were mostly distributed in the pH range from 6.5 to 8.0 , without significant concentrations in the high alkaline range of more than pH 8.0. These results suggest that there exist distinct anti-DNA clonotypes in each mouse strain and that the development of lupus nephritis does not appear to be associated with particular spectrotypes of anti-DNA antibodies. Rather, the age-dependent expansion of anti-DNA clonotypes may be a feature more characteristic of mice developing lethal lupus nephritis.
\end{abstract}

\section{Introduction}

The occurrence of circulating anti-DNA antibodies is one of the abnormalities closely associated with the pathological manifestations of human and murine systemic lupus erythematosus (SLE). ${ }^{1}$ The involvement of DNA-anti-DNA immune com-

Address correspondence to Dr. Izui.

Received for publication 23 November 1984 and in revised form 28 March 1985.

1. Abbreviations used in this paper: AKR-lpr/lpr, AKR/J-lpr/lpr; B6lpr/lpr, C57BL/6J-lpr/lpr; C3H-lpr/lpr, C3H/HeJ-lpr/lpr; dsDNA, double-stranded DNA; ELISA, enzyme-linked immunosorbent assay; GBM, glomerular basement membrane; IC, immune complexes; IEF, isoelectric focusing; lpr, lymphoproliferation; mBSA, methylated BSA; MHC, major histocompatibility complex; MRL-lpr/lpr, MRL/MpJ-lpr/lpr; pI, isoelectric points; SLE, systemic lupus erythematosus; ssDNA, singlestranded DNA.

J. Clin. Invest.

(C) The American Society for Clinical Investigation, Inc.

$0021-9738 / 85 / 08 / 0685 / 10 \quad \$ 1.00$

Volume 76, August 1985, 685-694 plexes (IC) in the pathogenesis of lupus nephritis was demonstrated by the significant concentration of anti-DNA antibodies found in eluates from the diseased kidneys $(1,2)$. The induction of tolerance to DNA antigens in $(\mathrm{NZB} \times \mathrm{NZW}) \mathrm{F} 1$ mice prolonged their survival and decreased lupus nephritis, further supporting the pathogenic significance of anti-DNA antibodies $(3,4)$.

It has been suggested that the qualities of anti-DNA antibodies such as specificity or avidity or isotypes may be as important as their quantities in provoking renal disease (5-8). In addition, isoelectric focusing analysis (IEF) of serum antiDNA isoelectric spectrum (spectrotype), which is a reflection of the repertoire of anti-DNA-producing B cell clones (9), has demonstrated the development of new clonotypes of antiDNA antibodies that appeared to be coincident with the onset of renal disease in SLE-prone mice $(10,11)$. However, it is still unclear whether particular spectrotypes of anti-DNA antibodies are indeed associated with the development of lupus nephritis (12).

In the present study, we performed, by IEF, an extensive analysis and comparison of the anti-DNA spectrotypes in sera and renal eluates from autoimmune mice with or without lethal lupus nephritis. The first group consisted of three different lupus-prone mice (MRL/MpJ-lpr/lpr [MRL-lpr/lpr], $[N Z B \times N Z W] F 1$, and male BXSB) that develop severe autoimmune disease characteristic of SLE and die of glomerulonephritis (13). The second group consisted of three lymphoproliferation (lpr) congenic strains (C57BL/6J, AKR/J, and $\mathrm{C} 3 \mathrm{H} / \mathrm{HeJ}$ ) without apparent SLE backgrounds. The latter three strains of mice bearing the lpr gene develop only mild chronic glomerulonephritis late in life, despite the production of various autoantibodies, including anti-DNA antibodies (14, 15). Therefore, we thought it beneficial to compare the spectrotypes of anti-DNA antibodies and their age-related changes in these strains to determine whether the particular anti-DNA clonotypes are involved in the pathogenesis of lupus nephritis.

\section{Methods}

Mice. MRL-lpr/lpr and BXSB mice were purchased from The Jackson Laboratory, Bar Harbor, ME. (NZB $\times$ NZW)F1 female mice were bred in our colonies from the breeding pairs purchased from Olac 1976 Limited, Oxon, England. Three different congenic strains bearing the lpr gene in nonautoimmune background, C57BL/6J-lpr/lpr (B6lpr/lpr), AKR/J-lpr/lpr (AKR-lpr/lpr), and C3H/HeJ-lpr/lpr (C3H-lpr/ lpr), were originally developed by E. D. Murphy and J. B. Roths (The Jackson Laboratories) and have been bred in our colonies since 1981. With the exception of BXSB mice, only female mice were used in the present study. Mice were bled by retroorbital puncture and the sera were stored at $-20^{\circ} \mathrm{C}$ until use.

Preparation of DNA. Heat-denatured calf thymus DNA (Type V; Sigma Chemical Co., St. Louis, MO) was used as single-stranded DNA (ssDNA). Double-stranded DNA (dsDNA) was purified by digestion with $S 1$ nuclease (16) and by the subsequent fractionation with benzoyl-naphthoyl-DEAE cellulose column chromatography (17). Hydroxylapatite column chromatography (17) has shown no detectable 
amounts of ssDNA in this dsDNA preparation. Both ssDNA and dsDNA were labeled with ${ }^{125}$ I according to the methods of Commerford (18). The purity of ${ }^{125}$ I-dsDNA was documented by hydroxylapatite column chromatography. The specific activity of each labeled DNA was $3-4 \times 10^{6} \mathrm{cpm} / \mu \mathrm{g}$ of ssDNA and $2-3 \times 10^{6} \mathrm{cpm} / \mu \mathrm{g}$ of dsDNA.

Solid-phase anti-DNA assay. To measure the activities of antissDNA or anti-dsDNA antibodies solid-phase radioimmunoassay (RIA) or enzyme-linked immunosorbent assay (ELISA) was employed. For anti-ssDNA solid-phase RIA, polyvinyl chloride microtiter plates (Dynatech Laboratories, Inc., Dynatech Corp., Alexandria, VA) were coated with $50 \mu \mathrm{l}$ of ssDNA $(10 \mu \mathrm{g} / \mathrm{ml})$ in phosphate-buffered saline (PBS) for $3 \mathrm{~h}$ at $37^{\circ} \mathrm{C}$, followed by washing with PBS. After incubation with $0.5 \%$ bovine serum albumin (BSA) in PBS for $1 \mathrm{~h}$ at room temperature, $50 \mu$ l of samples diluted with $2 \%$ BSA in PBS containing $0.05 \%$ Tween 20 was added to the wells for an overnight incubation at $4^{\circ} \mathrm{C}$. After washing, wells were incubated with $50 \mu \mathrm{l}$ of ${ }^{125} \mathrm{I}$-labeled goat anti-mouse $\gamma$-chain specific antibody (Cappel Laboratories, Cochranville, PA) at $20-50 \times 10^{4} \mathrm{cpm} /$ well for $5 \mathrm{~h}$ at $4^{\circ} \mathrm{C}$, followed by washing with $\mathrm{PBS}$, and the bound radioactivity was counted.

In ELISA, polystylene microtiter plates (Flow Laboratories, Inc., McLean, VA) were coated with ssDNA and incubated with samples in the same way as in RIA. Wells were then incubated with alkaline phosphatase-conjugated goat anti-mouse $\gamma$-chain specific antibody for $5 \mathrm{~h}$ at $4^{\circ} \mathrm{C}$ at $1 \mu \mathrm{g} / \mathrm{ml}$ of antibody concentration. After washing five times, $1 \mathrm{mg} / \mathrm{ml}$ of enzyme substrate (paranitrophenyl phosphate; Sigma Chemical Co.) was added in $0.01 \mathrm{M}$ diethanolamine solution, $\mathrm{pH} 9.8$. The color intensity was measured at OD $405 \mathrm{~nm}$ with Titertek Multiskan (Flow Laboratories, Inc.). To determine anti-dsDNA antibody activities by ELISA, wells were coated with $0.1 \%$ protamine sulfate before $50 \mu \mathrm{l}$ of dsDNA $(10 \mu \mathrm{g} / \mathrm{ml})$ was added to the wells, according to the method of Klotz et al. (19). Samples and antibody conjugates were diluted with $10 \%$ normal goat serum in $2 \%$ BSA in PBS containing $0.05 \%$ Tween 20 to reduce the nonspecific binding of immunoglobulins to protamine sulfate. The results of IEF fractions are directly expressed as the OD $405 \mathrm{~nm}$ after background values are subtracted.

Farr anti-DNA assay. IgG anti-ssDNA antibodies in serially diluted sera from $l p r$ congenic mice were measured with a modified Farr DNA-binding RIA in the presence of $0.1 \mathrm{M} 2$-mercaptoethanol to inactivate specifically IgM antibodies (20).

Solid-phase assay for IgG. The concentration of IgG was quantitated by a solid-phase RIA or ELISA using goat anti-mouse $\boldsymbol{\gamma}$-chain specific antibody similar to that described for the determination of IgM (21). Levels of IgG were computed by referring to the standard curve obtained by mouse IgG (Miles Ames Div., Miles Laboratories, Inc., Elkhart, IN).

Analytical IEF. Analytical IEF was performed in a vertical slab gel electrophoresis apparatus (Bio-Rad Laboratories, Richmond, CA) with a modification of the procedure by Baumann and Chrambach (22) and Bionda et al. (23). The gel solution was composed of $4.25 \%$ acrylamide, $0.75 \% \quad N, N^{\prime}$-diallyltartardiamide, $8 \mathrm{M}$ urea, $2 \%$ Nonidet P-40 (NP-40), and 2\% ampholites (Ampholines; LKB Produkter, Bromma, Sweden), pH 3.5-5, 5-7, 6-8, 7-9, and 9-11. After the solution was degassed, $0.1 \% N, N, N^{\prime}, N^{\prime}$-tetramethylethylenediamine, $6.8 \mu \mathrm{g} / \mathrm{ml}$ riboflavin 5 -phosphate, and $150 \mu \mathrm{g} / \mathrm{ml}$ ammonium persulfate were added to polymerize the solution. The gel $(14 \times 16 \times 0.15 \mathrm{~cm})$ was formed under fluorescent light for 4-5 h. The pore size of the gel excluded macromolecules such as IgM and Clq. The upper electrode chamber contained $0.05 \mathrm{M}$ phosphoric acid and $0.01 \mathrm{M}$ taurine; the lower electrode chamber contained $0.1 \mathrm{~N} \mathrm{NaOH}$ and $0.01 \mathrm{M}$ L-lysine. After the gel was prefocused for $1 \mathrm{~h}, 20 \mu \mathrm{l}$ of heat-inactivated serum or renal eluate containing 1-40 $\mu \mathrm{g}$ of IgG, diluted with $80 \mu \mathrm{l}$ of $6.7 \mathrm{M}$ urea solution containing 5\% Ampholine (pH 3.5-10) and 2\% NP-40, was loaded to a sample well and focused for 14-15 h at a constant voltage of 500 . Using high concentrations of urea and NP-40 permitted solubilization of proteins even in the form of IC in samples and prevented precipitation of proteins during focusing (23). Separated immunoglobulins were precipitated in $20 \%$ sodium sulfate solution for $4 \mathrm{~h}$ at room temperature, cross-linked with $4 \mathrm{mg} / \mathrm{ml}$ dimethylsuber- imidate in $0.05 \mathrm{M}$ phosphate buffer for $3 \mathrm{~h}$ at $4^{\circ} \mathrm{C}$, and washed with PBS overnight.

To reveal DNA-binding bands, gels were pretreated with $0.005 \%$ sodium dodecyl sulfate (SDS) in PBS at room temperature for $1 \mathrm{~h}$. Then, gels were incubated with sonicated ${ }^{125} \mathrm{I}$-DNA $\left(1-4 \times 10^{5} \mathrm{cpm} /\right.$ $\mathrm{ml}$ ) in PBS containing $0.005 \%$ SDS or in PBS for $16-20 \mathrm{~h}$ at room temperature. Unbound radioactivity was removed by extensive washing with PBS for $3 \mathrm{~d}$. After gels were dried, autoradiography was performed with Kodak X-Omat films. After 5-30 d exposure, the film was developed. In general, the number of DNA-binding bands did not change after 3 wk of exposure.

Densitometry of autoradiographic films was performed with a highresolution laser beam densitometer built in the laboratory of Prof. Gabbiani, Department of Pathology, University of Geneva. The scanning profile was analyzed by a computer (Microcomputer based on the S100 bus running under $\mathrm{CP} / \mathrm{M}$ operating system; Digital Research Inc., Pacific Grove, CA) programmed for scanning, which corrects base line and minimizes the background noise, as described by Kocher et al. (24).

Elution of separated immunoglobulins from analytical IEF gel. Immunoglobulins were eluted from the IEF gel by the following procedure. After the gel was focused, it was rapidly cooled at $-20^{\circ} \mathrm{C}$ for $2 \mathrm{~h}$ to precipitate urea on the surface of the gel. After the gel was washed three times for $1 \mathrm{~h}$ with PBS to remove urea and to adjust $\mathrm{pH}$, it was cut in 2- or 3-mm slices. Each gel slice was homogenized in $500 \mu \mathrm{l}$ of $1 \%$ BSA in PBS containing $0.05 \%$ Tween 20. After an overnight incubation at $4^{\circ} \mathrm{C}$, proteins eluted from the gel were obtained by centrifugation. IgG concentrations and IgG anti-DNA antibody activities in eluates from each IEF fraction were measured by solidphase RIA or ELISA. Using ${ }^{125}$ I-labeled mouse IgG, $\sim 50 \%$ of IgG were shown to be recovered from every IEF fraction by this procedure.

Elution of immunoglobulins from kidneys of autoimmune mice. The method similar to Dang and Harbeck (25) was used. Each of two pools of 8-10 kidneys from 4-5-mo-old MRL-lpr/lpr, 8-10-mo-old (NZB $\times$ NZW)F1 female, and 6-9-mo-old BXSB male mice was weighed, minced, and pressed through No. 200 stainless steel mesh (Bellco Glass, Inc., Vineland, NJ). Washed homogenates were incubated with DNase I (Worthington Biochemical Corp., Freehold, NJ) in $3 \times 10^{-3} \mathrm{M} \mathrm{MgCl}_{2}$ in PBS at $37^{\circ} \mathrm{C}$ for $2 \mathrm{~h}$ at $4^{\circ} \mathrm{C}$ overnight. After centrifugation, the first DNase eluate was separated. Then, the homogenates were further treated with $0.1 \mathrm{M}$ citrate buffer, $\mathrm{pH} 3.2$, at $37^{\circ} \mathrm{C}$ for $2 \mathrm{~h}$ to obtain the acid eluate. Both eluates were dialyzed against $0.01 \mathrm{M}$ phosphate buffer, $\mathrm{pH} 7.8$, pooled, and concentrated.

\section{Results}

Specific detection of DNA-binding bands in analytical IEF. To minimize the nonspecific binding to ${ }^{125}$ I-ssDNA by positively charged proteins or highly concentrated immunoglobulins in analytical IEF gels, the effect of SDS during the incubation of IEF gels with ${ }^{125}$ I-ssDNA was tested. In the absence of SDS, several significant ssDNA binding bands were obtained in the range of $\mathrm{pH}$ 6.8-8.0 by nonheated sera from 2-mo-old C57BL/ 6 and MRL-lpr/lpr mice (Fig. $1 \mathrm{~A}$ ). Some of these bands were diminished or removed by heating of sera at $56^{\circ} \mathrm{C}$ for $30 \mathrm{~min}$, but significant bindings were still observed, especially in the serum from 2-mo-old MRL-lpr/lpr mouse. $40 \mu \mathrm{g}$ of separated $\mathrm{IgG}_{2 \mathrm{a}}$ myeloma protein (LPC-1), which does not have any anti-DNA activity, developed the ssDNA-binding bands under this condition. Methylated BSA (mBSA), a basic protein, has also shown a strong binding to ${ }^{125} \mathrm{I}$-ssDNA, particularly in the range of $\mathrm{pH}$ 8.2-8.5. On the other hand, when the gel was pretreated with $0.005 \%$ SDS and incubated with ${ }^{125}$ I-sSDNA in the presence of $0.005 \%$ SDS (Fig. $1 B$ ), ssDNA-binding bands by sera from 2-mo-old C57BL/6, and MRL-lpr/lpr mice, LPC-1 myeloma protein and mBSA were markedly or com- 


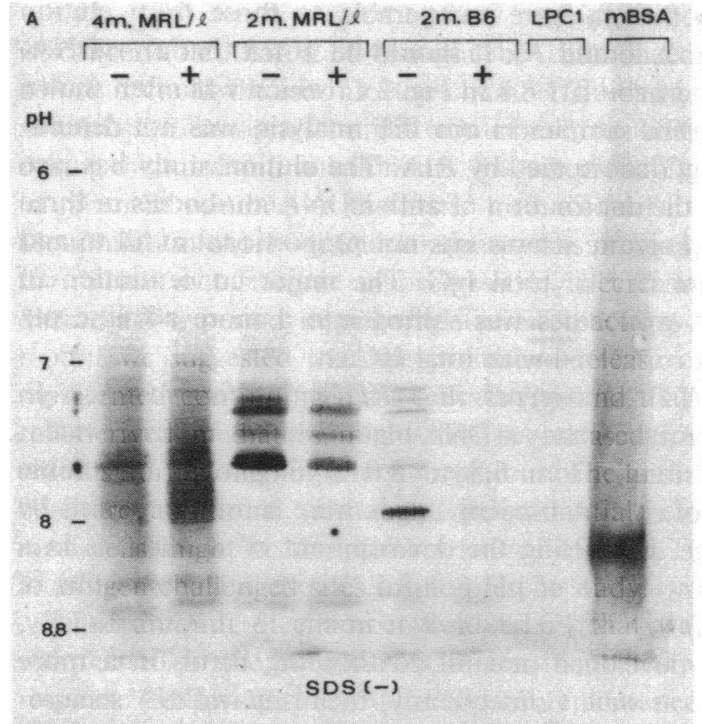

Figure 1. $20 \mu \mathrm{l}$ of sera from 4-mo-old MRL-lpr/lpr (4 m. MRL/1), 2mo-old MRL-lpr/lpr (2 m. MRL/1), and 2-mo-old B6 (2 m. B6) mice were subjected to IEF with $40 \mu \mathrm{g}$ of $\operatorname{IgG}_{2 \mathrm{a}}$ myeloma protein (LPC-1) and $25 \mu \mathrm{g}$ of mBSA in duplicated gels. After focusing,

pletely diminished. However, even under this condition, many of the ssDNA-binding bands obtained from serum from a 4 mo-old MRL-lpr/lpr mouse remained in the $\mathrm{pH}$ range of 6.5-
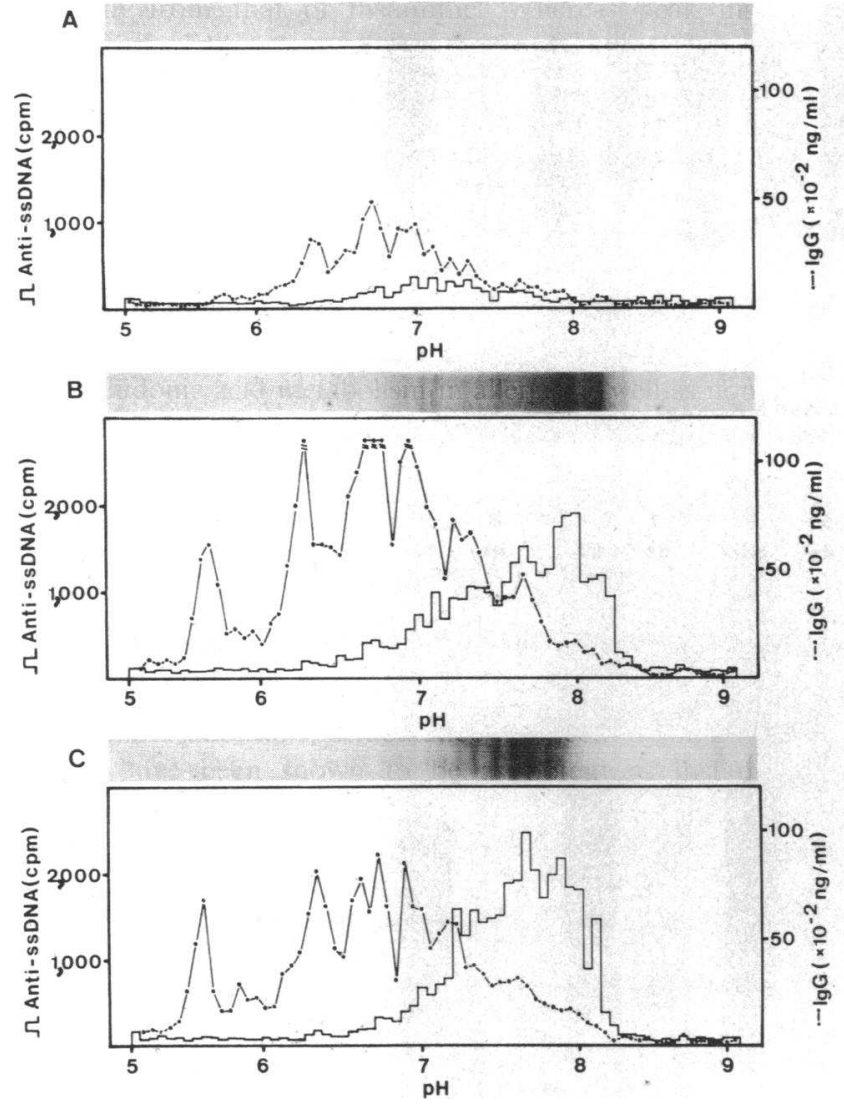

Figure 2. Serum proteins from 2-mo-old MRL-lpr/lpr $(A)$, three 5.5mo-old MRL-lpr/lpr $(B, C$, and $D), 10$-mo-old female (NZB $\times$ NZW)F1 $(E)$, and 6-mo-old male BXSB $(F)$ mice were separated by IEF in duplicate. Spectrotypes of ssDNA-binding bands were com- autoradiographs were obtained by incubating the gel with ${ }^{125} \mathrm{I}$-ssDNA without SDS $(A)$ or in the presence of $0.005 \% \operatorname{SDS}(B) .(-)$, Nonheated serum; $(+)$, heat-inactivated serum.

8.2 , almost the same intensity as that obtained without SDS. Therefore, throughout the study, the IEF gel was pretreated with $0.005 \%$ SDS and incubated with ${ }^{125} \mathrm{I}$-ssDNA in the
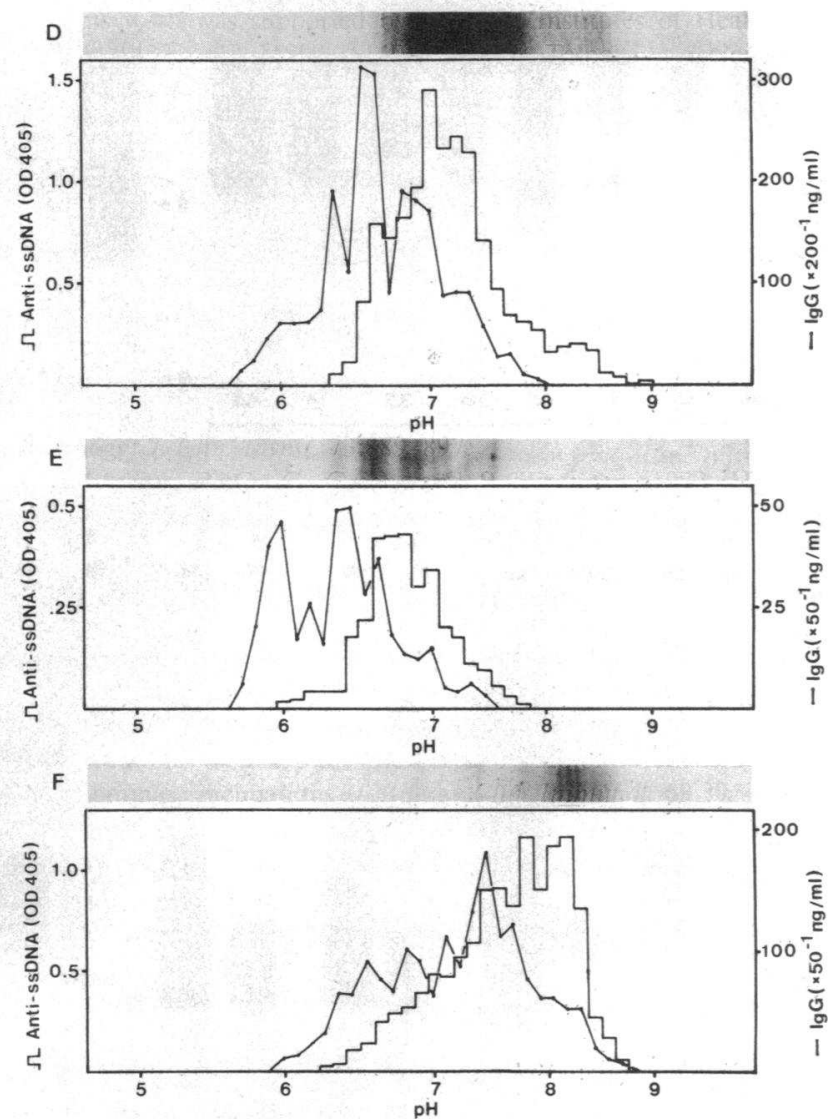

pared with the elution profiles from the gel slices of anti-ssDNA activities and IgG levels detected by RIA $(A, B$, and $C)$ or ELISA $(D$, $E$, and $F$ ). 
presence of $0.005 \%$ SDS. However, it should be noted that nonspecific bands were sometimes observed after the long time exposure of the film.

To assess the specificity of binding revealed by the autoradiography, immunoglobulins were eluted from IEF gel slices and their anti-ssDNA activities were determined by RIA or ELISA. Results were compared with the spectrotypes of ssDNAbinding bands of the duplicate samples in the same gel. Serum from a 2-mo-old MRL-lpr/lpr mouse showed a group of barely visible, weak ssDNA-binding bands in pH 6.7-7.2. Minimum bindings $(<400 \mathrm{cpm})$ to ssDNA were detectable by RIA in the same $\mathrm{pH}$ range from IEF gel eluates (Fig. $2 A$ ). When three sera from 5.5-mo-old MRL-lpr/lpr mice were analyzed, multiple but quite different ssDNA-binding bands were obtained from each sample in the pH range from 6.5 to 8.5. The elution study on anti-ssDNA activities of IEF gels from these sera gave results comparable to their autoradiographs (Fig. 2, B$D$ ). Similar studies were performed on sera from 10 -mo-old $(\mathrm{NZB} \times \mathrm{NZW}) \mathrm{F} 1$ female and 6-mo-old BXSB male mice. Results from ssDNA-binding bands obtained by autoradiog- raphy in both sera were comparable to those from elution studies (Fig. 2, $E$ and $F$ ). It should be noted that an ssDNAbinding band at $\sim \mathrm{pH} 8.8$ in Fig. $2 C$, which was often shown by other serum samples in our IEF analysis, was not demonstrated as IgG antibodies by RIA. The elution study has also shown that the distribution of anti-ssDNA antibodies in three different SLE-prone strains was not proportional at all to and distinct from that of total IgG. The major concentration of anti-ssDNA antibodies was shifted into a more alkaline $\mathrm{pH}$ range when compared with total IgG.

Anti-DNA spectrotypes in MRL-lpr/lpr female mice. In MRL-lpr/lpr mice, many ssDNA-binding bands became evident in the $\mathrm{pH}$ range from 6.8 to 8.0 at 3 mo of age. Some subgroups of ssDNA-binding bands were more intensified by 5 mo of age, paralleling the development of new bands in a more alkaline range of $\mathrm{pH}$ 8.0-8.5. Representative results of two MRL-lpr/lpr mice are shown in Fig. $3 \mathrm{~A}$. Occasionally, some mice developed new ssDNA-binding bands in a more acidic range as well. Consequently, their anti-ssDNA spectrotypes were extremely heterogeneous in pH 6.5-8.5 and differed
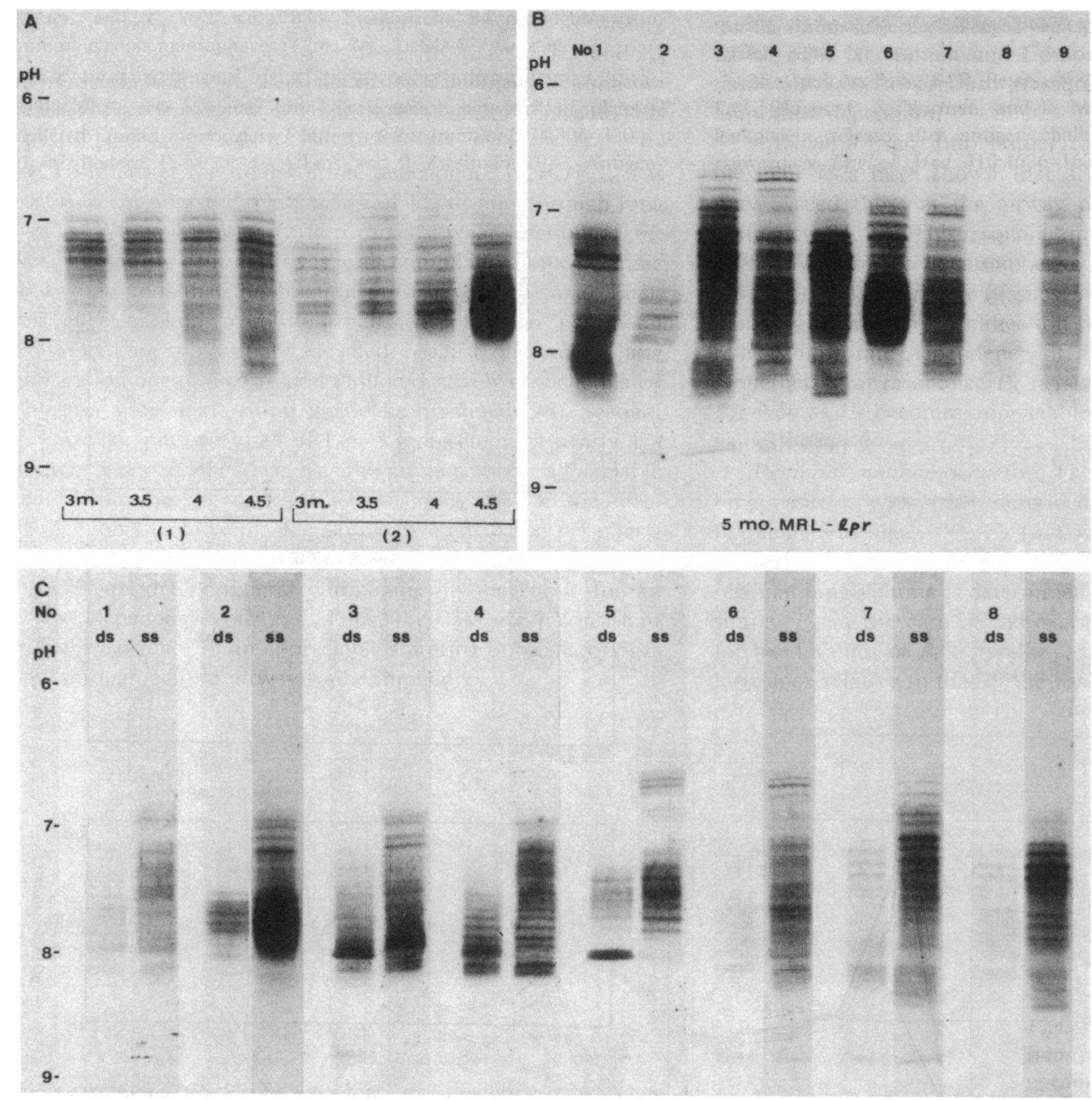

Figure 3. $(A)$ Age-dependent changes of ssDNA-binding bands in two MRL-lpr/lpr mice from $3(3 \mathrm{~m}$.) to 4.5 mo of age. $(B)$ ssDNAbinding bands in individual MRL-lpr/lpr mice of 5 mo of age. $(C)$
Comparison between dsDNA-binding bands (ds) and ssDNA-binding bands (ss) in eight individual MRL-lpr/lpr mice of 4.5-5 mo of age. 


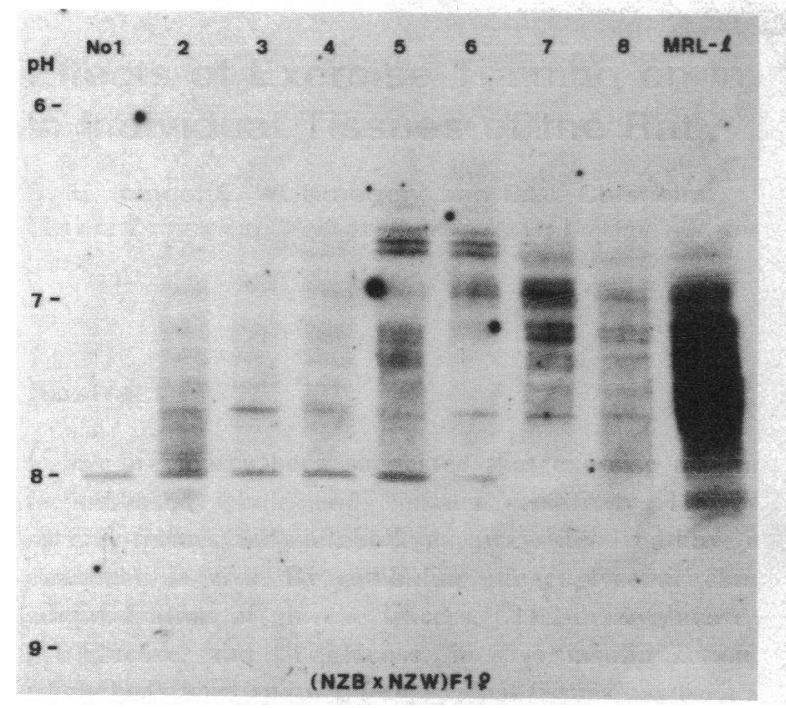

Figure 4. Anti-DNA spectrotypes in eight female $(\mathrm{NZB} \times \mathrm{NZW}) \mathrm{F} 1$ mice of 8-10 mo of age. For comparison, a serum from 5-mo-old MRL-lpr/lpr mouse (MRL-l) is included.

greatly among individual mice at 5 mo of age (Fig. $3 \mathrm{~B}$ ). When anti-dsDNA spectrotypes were compared with those of antissDNA in these mice, dsDNA-binding bands shared dominant bands reacting with ssDNA (Fig. $3 C$ ). Again, anti-dsDNA spectrotypes varied greatly among individual mice.

Anti-DNA spectrotypes in $(N Z B \times N Z W) F 1$ female mice. The ssDNA-binding bands in (NZB $\times$ NZW)F1 females began to be detectable at 6 mo of age. At 8-10 mo of age, at least five to six relatively distinct subgroups of ssDNA-binding bands became apparent in pH 6.5-8.0. Seven of eight sera tested exhibited these common bands, although intensity of each band varied among individual animals (Fig. 4). In contrast to the wide distribution of anti-ssDNA spectrotypes in MRL$l p r / l p r$ mice, $(\mathrm{NZB} \times \mathrm{NZW}) \mathrm{F} 1$ females did not develop significant alkaline bands of more than $\mathrm{pH} 8.0$ even later in their life. The faint but significant dsDNA-binding bands that corresponded to heavy ssDNA-binding bands were observed in these mice (data not shown).
Anti-DNA spectrotypes in BXSB male mice. The ssDNAbinding bands in male BXSB mice were relatively confined to the alkaline range of $\mathrm{pH} 7.8-8.5$. By 6 mo of age, these alkaline bands became more intensified with the development of relatively weak additional bands between pH 7-8 (Fig. 5 $A)$. In fact, 11 of 13 mice tested showed major alkaline ssDNAbinding bands characteristic of BXSB male mice (Fig. $5 \mathrm{~B}$ ). Similar alkaline bands of lesser intensity were observed with ${ }^{125}$ I-dsDNA (data not shown).

Anti-DNA spectrotypes in B6-lpr/lpr, AKR-lpr/lpr, and C3H-lpr/lpr female mice. Three strains of mice (B6, AKR, and $\mathrm{C} 3 \mathrm{H}$ ) bearing the lpr gene spontaneously produced significant amounts of anti-DNA antibodies $(14,15)$. However, their levels reached maximum at $\sim 6-8 \mathrm{mo}$ of age and decreased gradually. Most sera from 6-8-mo-old B6-lpr/lpr mice exhibited markedly restricted ssDNA-binding bands in alkaline $\mathrm{pH}$ from 7.8 to 8.4 , similar to those obtained by male BXSB mice (Fig. $6 A$ ). Only 1 of 20 mice examined developed additional bands in pH 7-7.5. In contrast, both AKR-lpr/lpr and $\mathrm{C} 3 \mathrm{H}-\mathrm{lpr} / \mathrm{lpr}$ mice at 6-8 mo of age showed a variety of anti-ssDNA spectrotypes differing in individual mice in the $\mathrm{pH}$ range from 6.5 to 8.2 (Figs. $7 \mathrm{~A}$ and $8 A$ ). The number of anti-ssDNA bands was relatively limited in these three $l p r$ mice as compared with MRL-lpr/lpr mice. Further, both the number and intensity of anti-ssDNA bands in these lpr mice decreased as they aged (Figs. $6 \mathrm{~B}, 7 \mathrm{~B}$, and $8 \mathrm{~B}$ ). At $12 \mathrm{mo}$ of age, ssDNA-binding bands were hardly detectable in the majority of mice.

To examine whether the difference in the number of ssDNA-binding bands between MRL-lpr/lpr and the other three $l p r$ strains was related to their anti-ssDNA antibody levels, various amounts of sera $(2.5-40 \mu \mathrm{l})$ from three MRLlpr/lpr (4.5-mo-old) and three B6-lpr/lpr (6-8-mo-old) mice, and one C3H-lpr/lpr (6-mo-old) and one AKR-lpr/lpr (6-moold) mouse were analyzed for their anti-ssDNA spectrotypes in the same experiment (Fig. 9). The measurement of IgG anti-ssDNA antibody levels by Farr assay of these samples showed comparable amounts ( $\pm 60 \%$ bindings) in sample Nos. 1, 7, 9 (B6-lpr/lpr), 5, 13, 18 (MRL-lpr/lpr), 14 (C3H-lpr/lpr), and 16 (ARK-lpr/lpr). In sera from three MRL-lpr/lpr mice, the individual anti-DNA spectrotypes were essentially identical, independent of the amounts of sera applied to the IEF gels

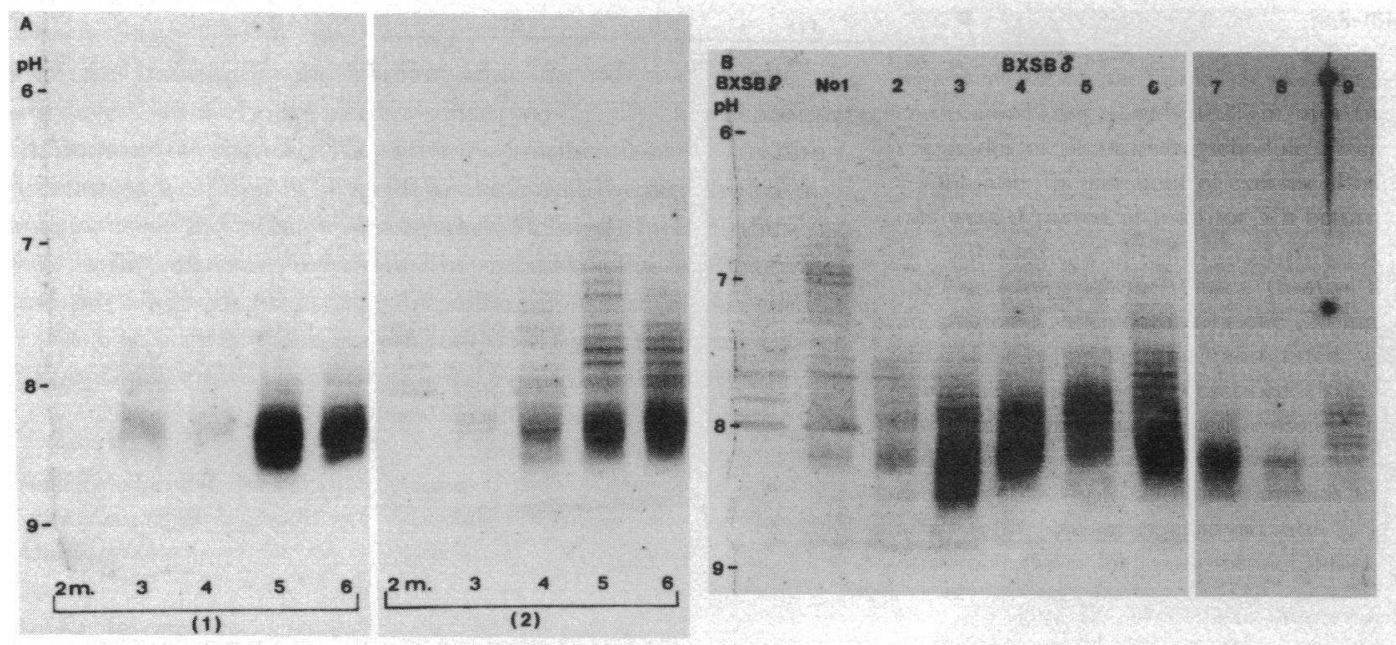

Figure 5. (A) Age-related changes of anti-DNA spectrotypes in two male BXSB mice from $2(2 \mathrm{~m}$.) to $6 \mathrm{mo}$ of age. (B) Anti-DNA spectrotypes in nine male BXSB mice of $6 \mathrm{mo}$ of age. A serum from 2-mo-old female BXSB mouse is included at the left end as a control. 


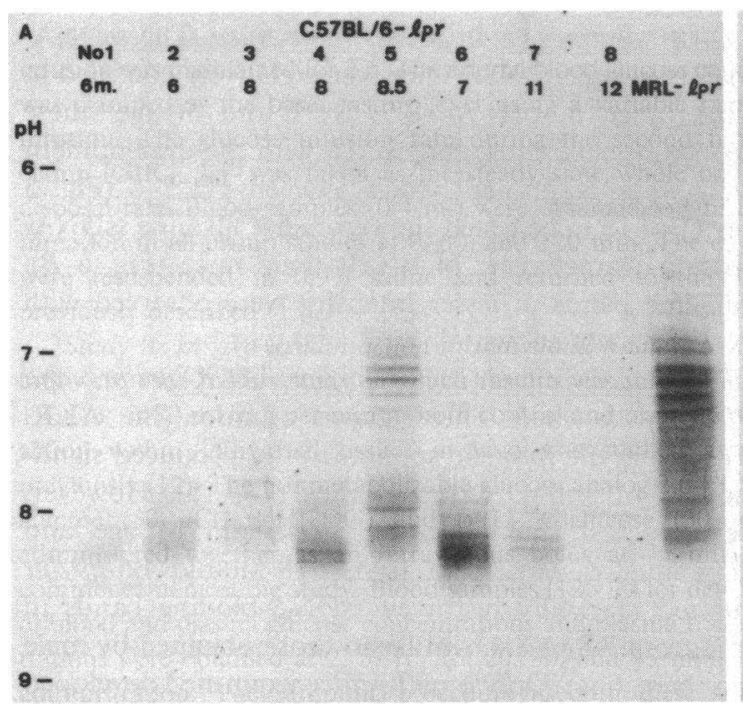

Figure 6. (A) Anti-DNA spectrotypes in individual B6-lpr/lpr mice of $6(6 \mathrm{~m}$.)-12 mo of age. A serum from 5-mo-old MRL-lpr/lpr (MRL-

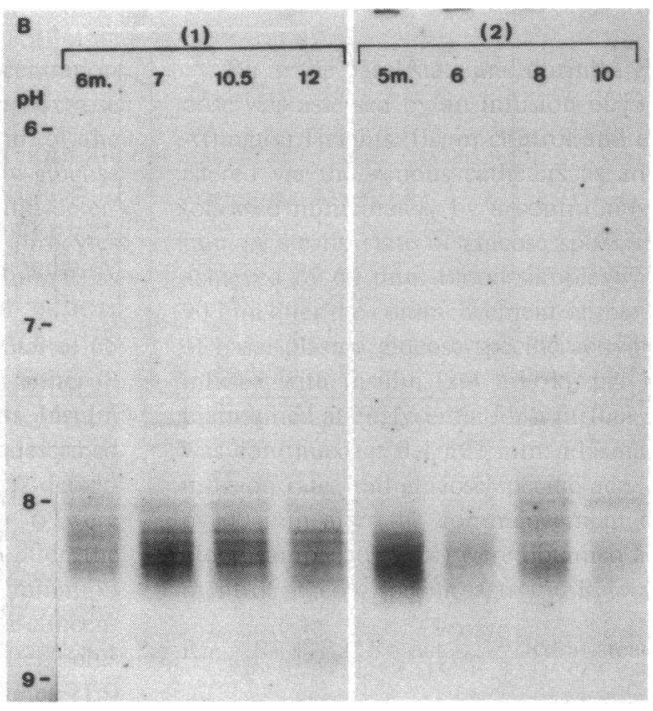

$l p r)$ is included at the right end. $(B)$. Age-related changes of antiDNA bands in two B6-lpr/lpr mice from 6-12 and 5-10 mo of age.
(Fig. $9 A$ ). In fact, all three MRL-lpr/lpr mice exhibited heterogeneous anti-DNA spectrotypes in pH 6.6-8.4 with the lowest amount of serum (Nos. 5, 13, and 18). However, samples from B6-lpr/lpr (Nos. 1, 7, and 9), C3H-lpr/lpr (No. 14), and AKR-lpr/lpr (No. 16), whose anti-DNA contents were comparable to those of sample Nos. 5, 13, and 18 from MRL-lpr/lpr, showed restricted spectrotypes in pH 7.8-8.4 for B6-lpr/lpr and in pH 7.0-8.0 for C3H-lpr/lpr and ARK-lpr/ lpr mice. Notably, no new anti-DNA clonotypes were revealed in sera from B6-lpr/lpr and ARK-lpr/lpr mice, even when twice as many sera $(40 \mu \mathrm{l})$ were used or when the IEF gels were exposed for longer periods.

Densitometric analysis on the same autoradiographic films confirmed the distinct spectrotypes of anti-DNA antibodies in these $l p r$ mouse strains. Representative results are shown in Fig. $9 \mathrm{~B}$. It should be noted that increasing amounts of a B6lpr/lpr serum from $20 \mu \mathrm{l}$ (No. 7) to $40 \mu \mathrm{l}$ (No. 6) did not result in the appearance of new spectrotypes. Likewise, when
IEF gels of Nos. 2-5 (20-2.5 $\mu$ l of serum) and Nos. 10-13 (20-2.5 $\mu \mathrm{l}$ of serum) from MRL-lpr/lpr mice were similarly analyzed, the number of anti-DNA spectrotypes in the lowest amount of sera (Nos. 5 and 13) was identical to that observed with the highest amount of sera (Nos. 2 and 10) (data not shown). These findings suggest that the difference in antiDNA spectrotypes among these $l p r$ strains was not a reflection of serum antibody concentrations but represented unique qualitative characteristics of each mouse strain.

Anti-DNA antibodies in renal eluates. Significant activities of anti-ssDNA and anti-dsDNA antibodies were recovered from renal eluates of MRL-lpr/lpr, $(\mathrm{NZB} \times \mathrm{NZW}) \mathrm{F} 1$, and male BXSB mice (Table I). Concentrations of anti-ssDNA antibodies in renal eluates were 10-40 times greater than those of anti-dsDNA antibodies. Relative concentrations of antissDNA antibodies in IgG eluted from the kidneys of three SLE-prone strains were from 3 to 18 times higher than those of anti-ssDNA antibodies in serum IgG. Anti-dsDNA anti-

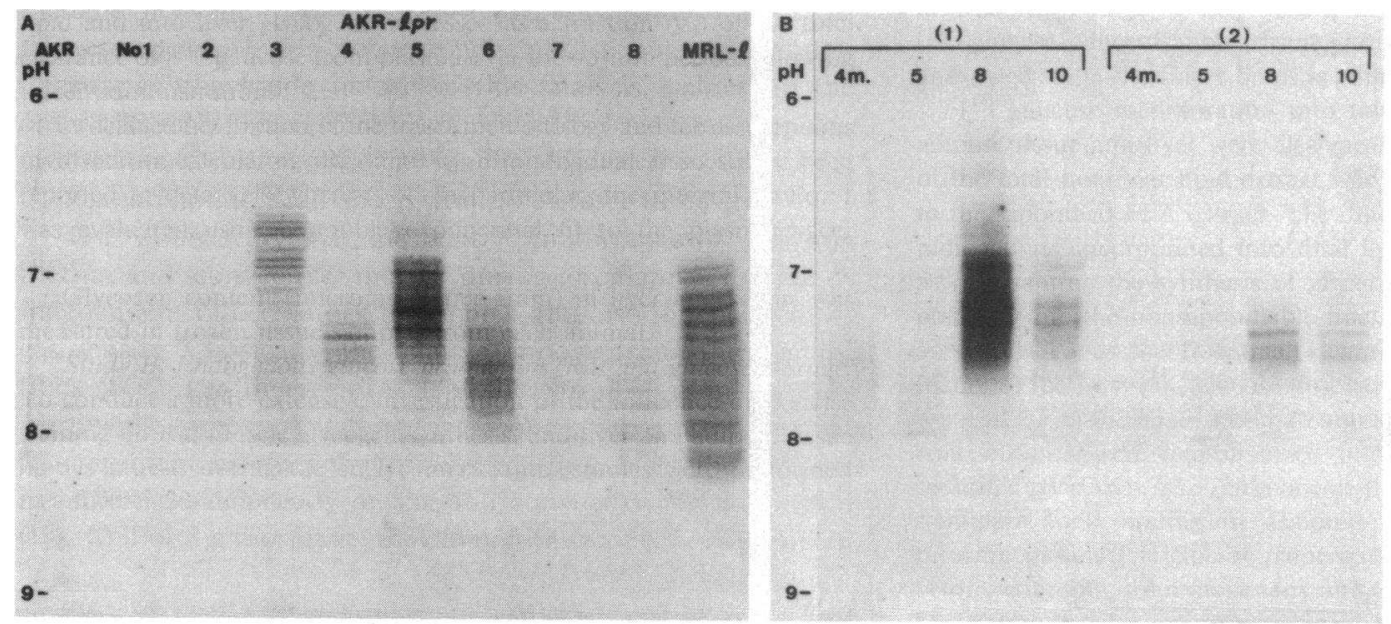

Figure 7. (A). Anti-DNA spectrotypes in individual AKR-lpr/lpr mice of 6-8 mo of age. For comparison, sera from 2-mo-old AKR (left end) and 5-mo-old MRL-lpr/lpr (right end) are included. (B) Age-

related changes of DNA-binding bands in two AKR-lpr/lpr mice from $4(4 \mathrm{~m}$.) to $10 \mathrm{mo}$ of age. 


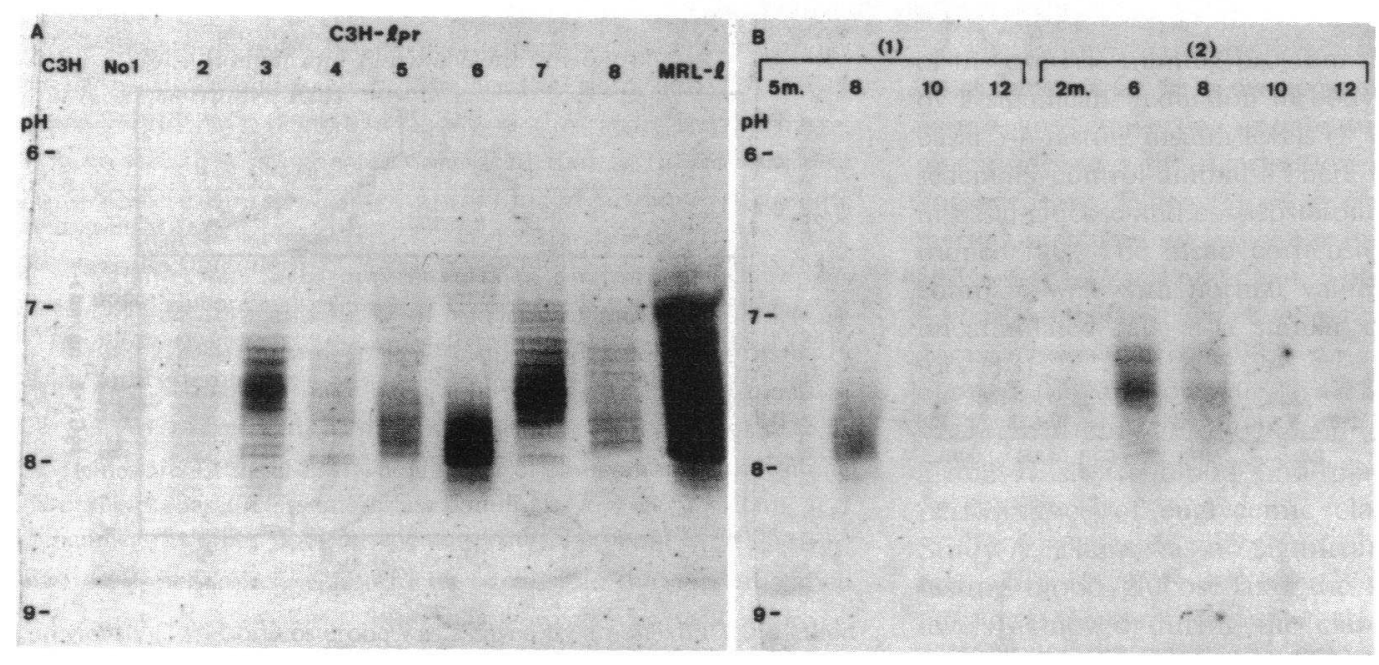

Figure 8. (A) Anti-DNA spectrotypes in individual C3H-lpr/lpr mice of 6-8 mo of age. Sera from 2-mo-old C3H (left end) and 5-mo-old MRL-lpr/lpr (right end) mice are compared. $(B)$ Age-related changes

of DNA-binding bands in two $\mathrm{C} 3 \mathrm{H}-l p r / l p r$ mice from $5(5 \mathrm{~m})-$. and 2-12 mo of age. bodies were also concentrated in renal eluates from these mice, being four to six times greater than in serum.

When anti-DNA spectrotypes of renal eluates from these lupus-prone mice were analyzed by analytical IEF, no welldefined DNA-binding bands were seen, although less sharp, dull bands were observed in high alkaline $\mathrm{pH}$ range $(\mathrm{pH} 8.2-$ 9.2). Therefore, immunoglobulins were eluted from IEF gel slices and their anti-ssDNA and anti-dsDNA antibodies were determined by ELISA in comparison with IgG levels. Representative results from renal eluates of MRL-lpr/lpr, (NZB $\times \mathrm{NZW}$ )F1, and male BXSB mice are shown in Fig. 10. All three renal eluates showed almost identical spectrotypes of anti-ssDNA and anti-dsDNA antibodies. Most of both antissDNA and anti-dsDNA activities were distributed within pH 6.5-8.0. However, it should be noted that there was no significant anti-DNA activity detectable by ELISA in high alkaline $\mathrm{pH}$ range of more than $\mathrm{pH} 8.0$ in any eluates. Spectrotypes of IgG from renal eluates were mostly obtained in $\mathrm{pH} 6-8$, peaking at around $\mathrm{pH}$ 7.0. Again, there were no detectable amounts of $\mathrm{IgG}$ in alkaline range of more than $\mathrm{pH}$ 8.0 in any renal eluates.

\section{Discussion}

In the present study, we analyzed and compared the spectrotypes of IgG anti-DNA antibodies in various autoimmune mice by IEF in relation to the pathogenesis of lupus nephritis. Our results demonstrated that each murine strain bears distinct spectrotypes of anti-DNA antibodies and that the development of lupus nephritis does not appear to be associated with particular spectrotypes of anti-DNA antibodies. Rather, the age-dependent expansion of anti-DNA clonotypes appears to be more characteristic in mice developing lethal lupus nephritis.

It is clear that the use of low concentration SDS $(0.005 \%)$ during the incubation of the focused gel with ${ }^{125} \mathrm{I}$-DNA enhanced the specificity of DNA-binding bands because of the elimination of the binding with basic proteins. Such concentration of SDS almost completely eliminated nonspecific bands

Table I. Comparison of Concentrations of IgG, Anti-ssDNA, and Anti-dsDNA Antibodies between Renal Eluates and Corresponding Sera from Three Strains of Lupus-prone Autoimmune Mice

\begin{tabular}{|c|c|c|c|c|c|c|c|}
\hline Samples of & $\mathrm{Ig}^{*}$ & Anti-ssDNAł & Anti-ssDNA/IgG & $\begin{array}{l}\text { Concentration } \\
\text { index of } \\
\text { anti-ssDNA§ }\end{array}$ & Anti-dsDNA" & Anti-dsDNA/IgG & $\begin{array}{l}\text { Concentration } \\
\text { index of } \\
\text { anti-dsDNAT }\end{array}$ \\
\hline & & & $\%$ & & & $\%$ & \\
\hline \multicolumn{8}{|l|}{ MRL-Ipr/lpr } \\
\hline Renal eluate & 39 & 1.26 & 3.23 & \multirow{2}{*}{2.8} & 0.12 & 0.31 & \multirow{2}{*}{4.4} \\
\hline Serum & 41,500 & 486 & 1.17 & & 29 & 0.07 & \\
\hline \multicolumn{8}{|c|}{$(\mathrm{NZB} \times \mathrm{NZW}) \mathrm{F} 1$} \\
\hline Renal eluate & 57 & 4.52 & 7.93 & \multirow{2}{*}{17.6} & 0.12 & 0.21 & \multirow{2}{*}{4.2} \\
\hline Serum & 13,100 & 59 & 0.45 & & 6 & 0.05 & \\
\hline \multicolumn{8}{|l|}{ BXSB male } \\
\hline Renal eluate & 66 & 0.56 & 0.85 & \multirow{2}{*}{12.1} & 0.04 & 0.06 & \multirow{2}{*}{6.0} \\
\hline Serum & 9,500 & 7 & 0.07 & & 1 & 0.01 & \\
\hline
\end{tabular}

*. $\ddagger$ "l The concentrations of IgG, anti-ssDNA, and anti-dsDNA antibodies are expressed as micrograms per gram of kidneys for renal eluate and micrograms per milliliter for serum. $\$$. 1 Concentration index of anti-ssDNA or anti-dsDNA antibodies is expressed by the ratio of anti-ss(or ds)DNA/IgG in renal eluate to anti-ss(or ds)DNA/IgG in serum. 
A

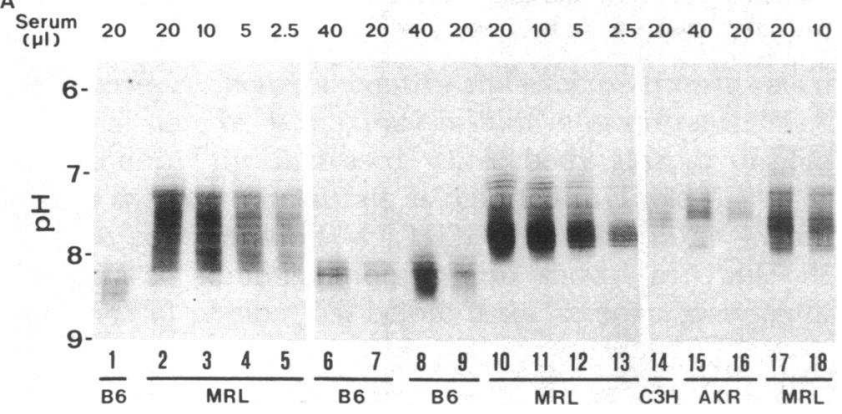

B
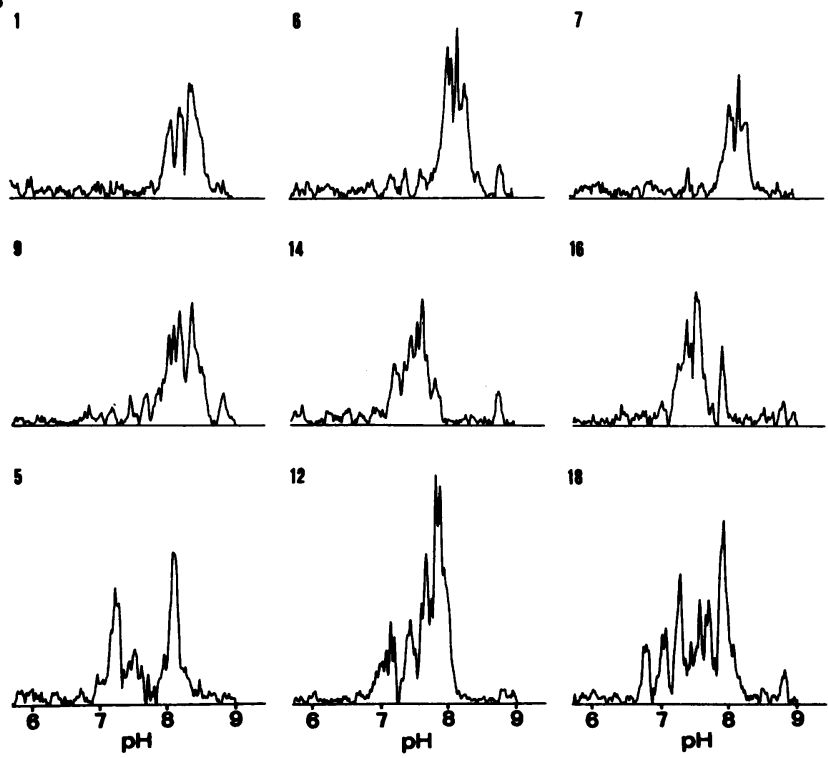

Figure 9. (A) Anti-ssDNA spectrotypes in three different MRL-lpr/lpr (MRL) mice (4.5-mo-old) were compared with those in three B6-lpr/ lpr (B6) mice, one C3H-lpr/lpr (C3H) mouse, and one AKR-lpr/lpr (AKR) mouse (6-8-mo-old) in the same experiment. Various amounts $(2.5-40 \mu \mathrm{l})$ of sera were analyzed for comparison. For example, spectrotypes of samples 2-5 were obtained from the same MRL-lpr/lpr mouse using four different amounts of serum as indicated. Note that sample Nos. 1, 7, 9, 14, and 16, which exhibited ssDNA-binding activities comparable to those of sample Nos. 5, 13, and 18, showed limited numbers of ssDNA-binding bands. $(B)$ Densitometric analysis with programmed background reduction and baseline correction of the DNA-binding bands of nine samples in Fig. 9 $A$. The sample numbers coincide with those in Fig. $9 A$. Intensity of the bands is expressed in the same vertical scale. The results were comparable to the spectrotypes shown in Fig. $9 A$ with high resolution.

obtained by non-DNA binding immunoglobulins such as myeloma protein, LPC-1, or mBSA. It also reduced the DNAbinding bands seen in 2-mo-old nonautoimmune B6 mice without affecting the intensity and number of DNA-binding bands of sera from adult SLE mice. Such an effect of SDS has been demonstrated for the specific determination of anti-DNA antibodies by the Farr-DNA binding RIA (26). Although the use of SDS may affect the detection of low avidity anti-DNA antibodies, the elution study has demonstrated the correlation of DNA-binding bands obtained in the presence of SDS with the anti-DNA binding activities determined by solid-phase RIA or ELISA, which can detect low as well as high avidity
A

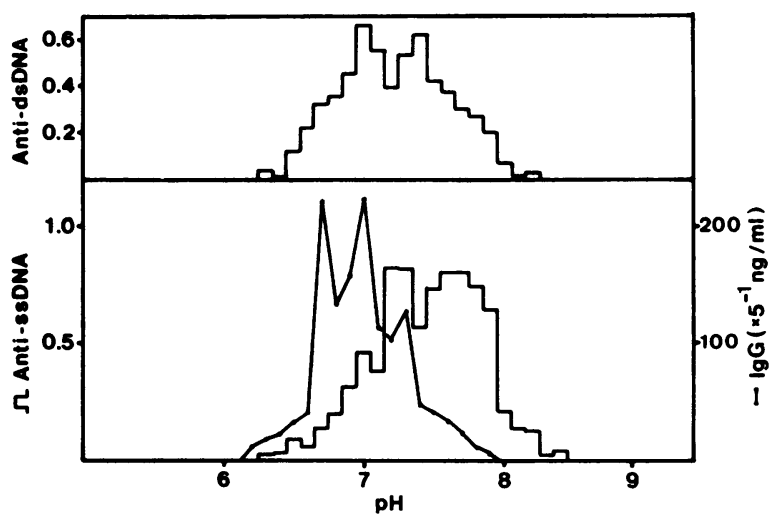

B

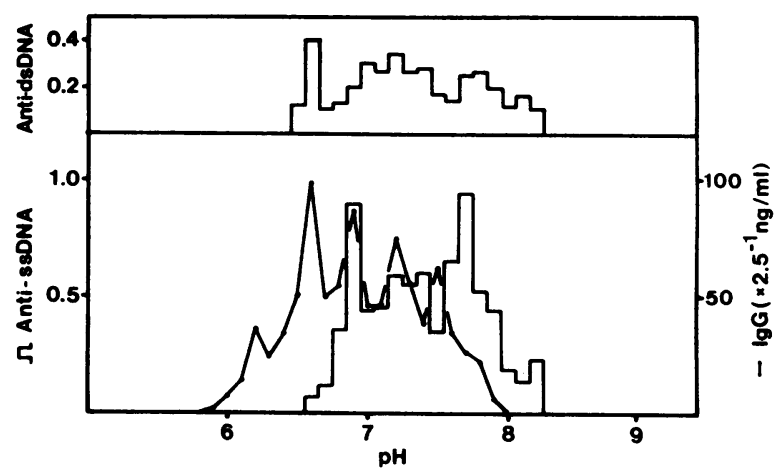

C

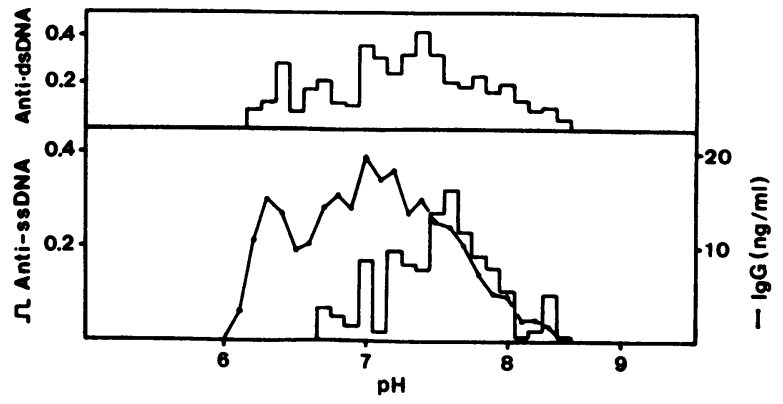

Figure 10. Spectrotypes of anti-dsDNA and anti-ssDNA activities and IgG levels in IEF fractions from renal eluates. (A) 4-5-mo-old MRL$l p r / l p r$ mice; (B) 8-10-mo-old (NZB $\times$ NZW)F1 mice; (C) 6-9-moold BXSB male mice.

antibodies (27). It should also be noted that anti-DNA binding activity eluted from the IEF gel was not correlated with the concentration of immunoglobulins, an observation supporting the specific detection of DNA-binding bands in our assay. However, one should be aware that even in the presence of SDS several samples, particularly renal eluates, showed dull DNA-bindings, occasionally in high alkaline range, which did not appear to be IgG anti-DNA antibodies.

When the dsDNA-binding bands were compared with ssDNA-binding bands in sera from autoimmune mice, almost all of anti-dsDNA bands shared strong anti-ssDNA bands in spite of the high purity of ${ }^{125} \mathrm{I}-\mathrm{dsDNA}$ preparation. Since it has been shown that most of anti-dsDNA antibodies bind to both dsDNA and ssDNA (28-31), it is likely that our ssDNA- 
binding bands reflect the total expression of both anti-ssDNA and anti-dsDNA antibodies.

Analysis of anti-DNA spectrotypes in SLE-prone mice developing lethal glomerulonephritis has demonstrated that each strain has distinct and characteristic spectrotypes of antiDNA antibodies. MRL-lpr/lpr mice exhibited the most heterogeneous spectrotypes of anti-DNA antibodies, with marked variation in individual animals. In contrast, in female (NZB $\times$ NZW)F1 and male BXSB mice anti-DNA spectrotypes were relatively uniform. Female $(\mathrm{NZB} \times \mathrm{NZW}) \mathrm{F} 1$ mice appeared to bear five to six common clonotypes in pH 6.5-8.0, and the major anti-DNA spectrotype of male BXSB mice was confined to a pH range from 7.8 to 8.5 . This limited size of anti-DNA spectrotypes in BXSB mice would explain a relatively low concentration of anti-DNA antibodies in this strain as shown in the present study and others $(13,20)$. Our results are contrasted with the recent observation that the most frequent anti-DNA antibodies common in these three autoimmune mice were focused in the alkaline range from $\mathrm{pH} 8.0$ to 8.5 (10). The difference between our results and theirs may be partly related to the use of SDS, which efficiently eliminated the binding of DNA by cationic nonimmunoglobulin proteins.

It has been recently suggested that the anti-DNA antibodies with isoelectric points (pI) from 8 to 9 may be more pathogenic because of the appearance of such alkaline anti-DNA antibodies coincident with the onset of renal disease and the concentration of these antibodies in renal eluates (10). This hypothesis was further supported by the findings that highly positively charged immunoglobulins (32) or immune complexes (33) could localize in glomerular basement membrane (GBM) through electrostatic interaction with the anionic sites in $\operatorname{GBM}(34,35)$ compared with those having neutral or acidic pI. However, our results have demonstrated that the development of lupus nephritis does not appear to be associated with particular spectrotypes of anti-DNA antibodies. First, the appearance of alkaline anti-DNA clonotype with high pI was not a common feature of mice developing severe glomerulonephritis. Second, B6-lpr/ lpr mice produced relatively high concentration of alkaline anti-DNA antibodies but failed to develop severe renal disease. Third, not only anti-DNA antibodies but also IgG was eluted from diseased kidneys, distributed mostly in the range of $\mathrm{pH}$ 6.5-8.0 without any concentration of particular clonotypes of alkaline pI $>8.0$. Autoradiographs of DNA bindings by renal eluates from nephritic autoimmune mice have shown dull DNA bindings in high $\mathrm{pH}$ range ( $\mathrm{pH}$ 8.2-9.2) similar to those described previously (10). However, such bands did not appear to be IgG anti-DNA antibodies because highly sensitive and specific ELISA failed to demonstrate anti-DNA antibodies or IgG in this high alkaline range. In fact, our results are compatible with the recent studies which have demonstrated no significant correlation between the alkaline anti-DNA spectrotype of serum and renal disease in human SLE (12). It should be noted that cationic IC composed of unmodified focused fractions of antigens and antibodies (pI 8-10) did not bind significantly to GBM compared with the high binding activity of IC composed of chemically modified cationic antigens and antibodies (33).

Instead, our results suggest that the age-dependent expansion of anti-DNA clonotypes may be more characteristic of mice that develop fatal glomerulonephritis. In fact, only mice developing fatal glomerulonephritis exhibited clonal expansion of anti-DNA antibodies throughout their lives. New spectro- types can be developed not only in the alkaline range but also in the acidic range. However, such expansion was not apparent in three lpr congenic mice that failed to develop severe glomerulonephritis. Their expression of anti-DNA spectrotypes rather decreased when they became old (>10 mo).

It is significant that spectrotypes of anti-DNA antibodies differed in three different congenic inbred strains bearing the lpr mutation, although their serum levels of anti-ssDNA antibodies were comparable (14). Apparently, the expression of anti-DNA spectrotypes was greatly influenced by the background genome of each strain. Of interest, B6-lpr/lpr mice have the major anti-DNA spectrotype in alkaline range similar to that observed in BXSB mice. Since both strains have the same immunoglobulin allotype (Igh- $\left.1^{b}\right)$ and major histocompatibility complex (MHC) haplotype $\left(\mathrm{H}-2^{\mathrm{b}}\right)(13,36)$, such a limited spectrotype in these mouse strains may be related to the immunoglobulin allotype gene or MHC-linked Ir gene for the specific immune response to DNA antigen. In fact, MRL$l p r / l p r, \mathrm{C} 3 \mathrm{H}-l p r / l p r$, and AKR-lpr/lpr mice that bear $\mathrm{H}-2^{\mathrm{k}}$ haplotype express different anti-DNA spectrotypes from B6lpr/lpr and BXSB mice. Experiments using B6-lpr/lpr mice congenic for the immunoglobulin allotype gene or MHC gene would help elucidate the understanding of the differences in anti-DNA spectrotypes in various strains of mice.

\section{Acknowledgments}

We thank Dr. Peter A. Miescher for his support, Dr. Alberto Bionda for valuable suggestions and discussions during the course of this investigation, and Dr. Olivier Kocher for his help with the densitometric analysis. The secretarial assistance of Mrs. Martine Devouge is appreciated.

This work was supported by grants 3.621.0.84 and 3.826.0.83 from the Swiss National Foundation for Scientific Research, by the World Health Organization, by the Dubois-Ferrière/Dinu Lipatti Foundation, and by the Kroc Foundation.

\section{References}

1. Koffler, D., P. H. Schur, and H. G. Kunkel. 1967. Immunological studies concerning the nephritis of system lupus erythematosus. $J$. Exp. Med. 126:607-624.

2. Lambert, P. H., and F. J. Dixon. 1968. Pathogenesis of the glomerulonephritis of NZB/W mice. J. Exp. Med. 127:507-522.

3. Borel, Y., R. M. Lewis, and B. D. Stoller. 1973. Prevention of murine lupus nephritis by carrier dependent induction of immunologic tolerance to denatured DNA. Science (Wash. DC). 182:76-78.

4. Parker, L. P., B. H. Hahn, and C. K. Osterland. 1984. Modification of NZB/NZW F1 autoimmune disease by development of tolerance to DNA. J. Immunol. 113:292-297.

5. Yoshida, H., A. Kohno, K. Ohta, S. Hirose, N. Maruyama, and T. Shirai. 1981. Genetic studies of autoimmunity in New Zealand mice. III. Associations among anti-DNA antibodies, NTA, and renal disease in (NZB $\times \mathrm{NZW)F1} \times$ NZW backcross mice. J. Immunol. 127:433-437.

6. Papoian, R., R. Pillarisetty, and N. Talal. 1977. Immunological regulation of spontaneous antibodies to DNA and RNA. II. Sequential switch from IgM to IgG in NZB/NZW F1 mice. Immunology. 32:7579.

7. Kohno, A., H. Yoshida, K. Sekita, N. Maruyama, S. Ozaki, S. Hirose, and T. Shirai. 1983. Genetic regulation of the class conversion of dsDNA-specific antibodies in $(\mathrm{NZB} \times \mathrm{NZW}) \mathrm{F} 1$ hybrid. Immunogenetics. 18:513-524.

8. Steward, M. W., F. E. Katz, and N. J. West. 1975. The role of low affinity antibody in immune complex disease. The quantity of 
anti-DNA antibodies in NZB/W F1 hybrid mice. Clin. Exp. Immunol. 21:121-130.

9. Williamson, A. R. 1978. Isoelectric focusing of immunoglobulins. In Handbook of Experimental Immunology. Vol. 1. D. M. Weir, editor. Blackwell Scientific Publications, Oxford. 9.1-9.31.

10. Ebling, F., and B. H. Hahn. 1980. Restricted subpopulations of DNA antibodies in kidneys of mice with systemic lupus. Comparison of antibodies in serum and renal eluates. Arthritis Rheum. 23:392403.

11. Dang, H., and R. J. Harbeck. 1982. A comparison of antiDNA antibodies from serum and kidney eluates of NZB $\times$ NZW F1 mice. J. Clin. Lab. Immunol. 9:139-145.

12. Fischbach, M., J. Rabbie, and N. Talal. 1981. Comparison of different antinucleic acid antibody spectrotypes in spontaneous, induced, and murine lupus. J. Clin. Invest. 68:1036-1043.

13. Andrews, B. S., R. A. Eisenberg, A. N. Theofilopoulos, S. Izui, C. B. Wilson, P. J. McConahey, E. D. Murphy, J. B. Roths, and F. J. Dixon. 1978. Spontaneous murine lupus-like syndromes. Clinical and immunopathological manifestations in several strains. J. Exp. Med. 148:1198-1215.

14. Izui, S., V. E. Kelley, K. Masuda, H. Yoshida, J. B. Roths, and E. D. Murphy. 1984. Induction of various autoantibodies by mutant lpr gene in several strains of mice. J. Immunol. 133:227-233.

15. Warren, R. W., S. A. Caster, J. B. Roths, E. D. Murphy, and D. S. Pisetsky. 1984. The influence of the $l p r$ gene on B cell activation: differential antibody expression in lpr congenic mouse strains. Clin. Immunol. Immunopathol. 31:65-77.

16. Shishido, K., and T. Ando. 1972. Estimation of the doublehelical content in various single-stranded nucleic acids by treatment with a single-strand-specific nuclease. Biochim. Biophys. Acta. 287: 477-484.

17. Locker, J. D., M. E. Medof, R. M. Bennett, and S. Sukhupunyaraksa. 1977. Characterization of DNA used to assay sera for antiDNA antibodies; determination of the specificities of anti-DNA antibodies in SLE and non-SLE rheumatic disease states. $J$. Immunol. 118:694-701.

18. Commerford, S. L. 1971. Iodination of nucleic acids in vitro. Biochemistry. 10:1993-2000.

19. Klotz, J. L., R. M. Minami, and R. L. Teplitz. 1979. An enzyme-linked immunosorbent assay for antibodies to native and denatured DNA. J. Immunol. Methods. 29:155-165.

20. Izui, S., and R. A. Eisenberg. 1980. Circulating anti-DNArheumatoid factor complexes in MRL/l mice. Clin. Immunol. Immunopathol. 15:536-551.

21. Izui, S., R. A. Eisenberg, and F. J. Dixon. 1979. IgM theumatoid factors in mice injected with bacterial lipopolysaccharides. J. Immunol. 122:2096-2102.

22. Baumann, G., and A. Chrambach. 1976. A highly crosslinked, transparent polyacrylamide gel with improved mechanical stability for use in isoelectric focusing and isotachophoresis. Anal. Biochem. 70: 32-38.
23. Bionda, A., M. H. de Baets, S. J. Tzartos, J. M. Lindstrom, W. O. Weigle, and A. N. Theofilopoulos. 1984, Spectrotypic analysis of antibodies to acetylcholine receptors in experimental autoimmune myasthenia gravis. Clin. Exp. Immunol. 57:41-50.

24. Kocher, O., O. Skalli, D. Cerutti, F. Gabbiani, and G. Gabbiani. 1985. Cytoskeletal features of rat aortic cells during development: an electron microscopic, immunohistochemical and biochemical study. Circ. Res. In press.

25. Dang, H., and R. J. Harbeck. 1984. The in vivo and in vitro glomerular deposition of isolated anti-double-stranded-DNA antibodies in NZB/W mice. Clin. Immunol. Immunopathol. 30:265-278.

26. Izui, S., P. H. Lambert, and P. A. Miescher. 1976. Determination of anti-DNA antibodies by a modified ${ }^{125}$ I-labelled DNA-binding test. Elimination of nonspecific binding of DNA to non-immunoglobulin basic proteins by using an anionic detergent. Clin. Exp. Immunol. 26: 425-430.

27. Smeenk, R., T. Duin, O. Suarez, and L. Aarden. 1982. Detection of antibodies to DNA by an enzyme-linked immunosorbent assay. In Low Avidity Antibodies to dsDNA. R. Smeenk, editor. Rodopi, Amsterdam. 141-162.

28. Koffler, D., R. Carr, V. Agnello, R. Thoburn, and H. G. Kunkel. 1971. Antibodies to polynucleotides in human sera: antigenic specificity and relation to disease. J. Exp. Med. 134:294-312.

29. Hahn, B. H., F. Ebling, S. Freeman, B. Clevinger, and J. Davie. 1980. Production of monoclonal murine antibodies to DNA by somatic cell hybrids. Arthritis Rheum. 23:942-945.

30. Tron, F., D. Charron, J. F. Bach, and N. Talal. 1980. Establishment and characterization of a murine hybridoma secreting monoclonal anti-DNA autoantibody. J. Immunol. 125:2805-2809.

31. Marion, T. N., A. R. Lawton III, J. F. Kearney, and D. E. Briles. 1982. Anti-DNA autoantibodies in $(\mathrm{NZB} \times \mathrm{NZW}) \mathrm{F} 1$ mice are clonally heterogeneous, but the majority share a common idiotype. J. Immunol. 128:668-674.

32. Oite, T., R. Batsford, M. J. Mihatsh, H. Takamiya, and A. Vogt. 1982. Quantitative studies of in situ immune complex glomerulonephritis in the rat induced by planted, cationized antigen. J. Exp. Med. 155:460-474.

33. Gallo, G. R., T. Caulin-Glaser, and M. E. Lamm. 1981. Charge of circulating immune complexes as a factor in glomerular basement membrane localization in mice. J. Clin. Invest. 67:1305-1313.

34. Rennke, H. G., R. S. Cotran, and M. V. Venkatachalam. 1975. Role of molecular charge in glomerular permeability. Tracer studies with cationic ferritins. J. Cell Biol. 67:638-646.

35. Kanwar, Y. S., and M. G. Farquhar. 1976. Anionic sites in the glomerular basement membrane. In vivo and in vitro localization to the lamina rarae by cationic probes. J. Cell Biol. 81:137-153.

36. Murphy, E. D., and J. B. Roths. 1978. Autoimmunity and lymphoproliferation: induction by mutant gene $l p r$, and acceleration by a male-associated factor in strain BXSB mice. In Genetic Control of Autoimmune Disease. N. R. Rose, P. E. Bigazzi, and N. L. Warner, editors. Elsevier Science Publishing Co. Inc., New York. 207-221. 